\title{
Relationships between Overstory Structure and Understory Production in the Grand Fir /Myrtle Boxwood Habitat Type of Northcen- tral Idaho
}

\author{
DAVID A. PYKE AND BENJAMIN A. ZAMORA
}

\section{Abstract}

Relationships between overstory structure and understory current year production on 20 undisturbed sites of the grand fir/myrtle boxwood habitat type were studied in the Clearwater Mountains of northcentral Idaho. Overstory characteristics measured were tree canopy coverage, sum of the tree diameters, basal area, stand height, and stem density. Understory production was divided into four vegetation classes: (1) shrubs, (2) forbs, (3) graminoid and (4) total production. Regression models predicting current year production of each understory vegetation class were developed using all pussible combinations of overstory parameters as independent variables. Canopy coverage and sum of the tree diameters were found to be the best indices of understory production. Canopy coverage was most significantly correlated with total understory production and shrub production. Canopy coverage and sum of the tree diameters were the most significantly correlated overstory parameters with forb production. Graminoid production was not significantly correlated to any of the measured overstory parameters. Basal area, tree density, and stand height were not statistically related to the understory production. Further examination of the models is needed to validate these relationships over the range of the grand fir/myrtle boxwood habitat type. The models are not applicable to areas where recent disturbance such as logging, fire, or disease has affected overstory structure.

In forest stands, understory shrub and herb production available to herbivores is highly dependent on the structure of the tree overstory. Several studies have been conducted which relate understory production to overstory structure in forest stands and have proposed models to predict understory production based on tree stand characteristics such as basal area (Clary and Ffolliott 1966, Gaines et al. 1954, Halls and Shuster 1965, McConnell and Smith 1965) and canopy cover (Anderson et al. 1969; Cooper 1960; Ehrenreich and Crosby 1960; Halls and Shuster 1965; Jameson 1967; McConnell and Smith 1965, 1970; Young et al. 1967). The majority of the published accounts of overstory structureunderstory production relationships are for forests in the south, southwest, or midwest United States. Little work has been done relating overstory structure to understory production in the Pacific Northwest.

The objective of this was to determine relationships between overstory structure and understory current year production on undisturbed sites of the grand fir/myrtle boxwood (Abies grandis/ Pachistima myrsinites) habitat type in the Clearwater Mountains of northcentral Idaho.

Authors are graduate research assistant and associate professor and range scientist Department of Forestry and Range Management, Washington State University Pullman 99164. D. Pyke is now agricultural research technician, Department of Botany, Washington State University.

This paper is Scientific Paper SP 5837 of the College of Agriculture Research Center, Washington State University. Work was conducted under Project 0290 . The research herein was financed in part by a grant from the USDA expanded Douglas-fir Tussock Moth Research and Development Program

Manuscript received February 2, 1981.

\section{Study Area and Methods}

The study area was located in the Clearwater Ranger District, Nezperce National Forest, northcentral Idaho. Twenty study sites were selected to obtain a range overstory canopy coverage, basal area, stand height and stand density. All sites were of the grand fir/myrtle boxwood habitat type as described by Daubenmire and Daubenmire (1968). Overstories varied in maximum age breast height from 65 to 192 years. Site elevations range from $1120-1620$ $\mathrm{m}$ with aspects representing all cardinal directions and slopes ranging from $0-54 \%$.

Vegetation measurements were made within a $375-\mathrm{m}^{2}$ circular macroplot established on each site. Overstory canopy coverage was measured using a spherical densiometer leveled at $1 \mathrm{~m}$ above the ground at the center of the macroplots (Lemmon 1956). The densiometer employs a highly polished, convex, chrome mirror to reflect a large overhead area. Diameter at breast height was measured for all conifer trees over $1.4 \mathrm{~m}$ and used to calculate basal area in $\mathrm{m}^{2} /$ ha and sum of tree diameters in $\mathrm{m} / \mathrm{ha}$. Average height in meters of the combined dominant and codominant crown classes was determined with a clinometer. All trees greater than $1.4 \mathrm{~m}$ high were counted and stem density expressed as number of trees per hectare.

The understory vegetation was divided into four above-ground vegetation classes: (1) shrub, (2) forb, (3) graminoid, and (4) total production. Current year growth of these vegetation classes was sampled between August 9 and 17, 1976, the period of near maximum above-ground production for the year. The circular macroplot was bisected perpendicular to the contour of the slope and five, $0.45 \mathrm{~m}^{2}$ production microplots were systematically located in each half. One microplot in each half of the macroplot was randomly selected for harvesting. The vegetation production of each class in the remaining 4 microplots was estimated as a percentage of the production of their counter-part class in the microplot to be harvested (Mueggler 1976). All herbaceous vegetation in the harvest microplot was then clipped to the upper surface of the litter layer and separated into their respective vegetation classes. Current year growth of shrubs in the harvest microplot was clipped at the previous spring's bud scar. No vegetation above $3 \mathrm{~m}$ from the ground was included in the sample. The clippings were air-dried for 3 days, oven-dried for 12 hours at $60^{\circ} \mathrm{C}$, and weighed.

Estimation error was assessed by clipping all 10 microplots at 3 of the study sites after estimating production as described above. $A$ regression equation relating estimates to actual production was derived to correct for estimation error prior to calculating the production for each macroplot.

Canopy coverage and rooted frequency data were collected on each site to characterize species composition of the understory. Forty $2 \times 5 \mathrm{dm}$ microplots were systematically placed along two $20 \mathrm{~m}$ transects passing through the center of the macroplot, one parallel and one perpendicular to the contour of the slope (Daubenmire 1959).

The production and overstory data were plotted and inspected to ascertain appropriate regression models. Relationships between 
overstory structure (independent variables), and understory production (dependent variables) were analyzed using the general linear model (GLM procedure), stepwise regression maximum $\boldsymbol{R}^{2}$ improvement (STEPWISE procedure), and all possible regressions (RSQUARE procedure) of the Statistical Analysis System (SAS) (Helwig and Council 1979). Two general linear models were considered appropriate and tested for significance:

$$
\begin{aligned}
& \text { (1) } Y=a+b X \\
& \text { (2) } Y=a+b X^{-1} \\
& \text { where } Y=\text { understory production } \\
& X=\text { overstory variables. }
\end{aligned}
$$

The best significant $(\alpha \leq .01)$ single variable model for each dependent variable was selected.

Multiple independent variable models were also explored. The 3 multiple independent variable models tested were:

$$
\begin{aligned}
& \text { (3) } Y=a+b_{1} X_{1}+b_{2} X_{2} \ldots b_{n} X_{\mathrm{n}} \\
& \text { (4) } Y=a+b_{1} X_{1}^{-1}+b_{2} X_{2}^{-1} \ldots b_{\mathrm{n}} X_{\mathrm{n}}^{-1} \\
& \text { (5) all possible combinations of (3) and (4) where } X_{\mathrm{i}} \text { could be } \\
& \text { used only once in the equation either as } b_{\mathrm{i}} X_{\mathrm{i}} \text { or } b_{\mathrm{i}} X_{\mathrm{i}}^{-1 .}
\end{aligned}
$$

If the multiple independent variable model yielded a higher coefficient of determination $\left(R^{2}\right)$, then an $F$-test was used to determine if the multiple variable model $R^{2}$ value was significantly $(\alpha \leq .05)$ greater than the $R^{2}$ of the single variable model.

\section{Results}

The overstory on all study sites was dominated by grand fir. However 6 additional subordinate tree species were present in various proportions among the stands (Table 1). Fifteen of the 20 sites had overstory coverage greater than $75 \%$ (Table 2). Overstory coverages of less than $50 \%$ on undisturbed sites in the Clearwater Mountains were uncommon. Coverage of less than $50 \%$ was normally the result of recent disturbances such as logging, fire or disease. Disturbed areas were not sampled since the degree of disturbance can affect plant composition and production making comparisons difficult. A total of 136 vascular plant species were encountered among all 20 study sites. Constancy, canopy coverage, and rooted frequency for selected species sampled at the study sites are shown in Table 3.

\section{Total Production}

The relationship between overstory canopy coverage and total production was found to be highly significant $\left(R^{2}=0.76\right)$ (Table 4, Fig. 1). In addition, sum of the tree diameters and basal area were also significantly related to total production as single variables with $R^{2}$ values of 0.54 and 0.37 , respectively (Table 4).

None of the multiple independent variable models accounted for a significantly greater portion of the variability in total understory

\begin{tabular}{|c|c|c|c|}
\hline Variable & $\bar{x}$ & $s$ & Range \\
\hline \multicolumn{4}{|l|}{ Overstory } \\
\hline $\begin{array}{l}\text { Sum of the diameters } \\
(\mathrm{m} / \mathrm{ha})\end{array}$ & 147.5 & 46.5 & $59-214$ \\
\hline Canopy coverage $(\%)$ & 82.4 & 14.5 & $50-96$ \\
\hline Stand density (trees/ha) & 1406.0 & 1377.6 & $320-3040$ \\
\hline Basal area $\left(\mathrm{m}^{2} / \mathrm{ha}\right)$ & 34.0 & 14.2 & $14-67$ \\
\hline Stand height (m) & 27.2 & 7.2 & $11-34$ \\
\hline \multicolumn{4}{|l|}{ Understory } \\
\hline Total production $(\mathrm{kg} / \mathrm{h})^{1}$ & 370.0 & 174.4 & $153-807$ \\
\hline Shrub production $(\mathrm{kg} / \mathrm{h})^{1}$ & 128.3 & 140.5 & $3-511$ \\
\hline Forb production $(\mathrm{kg} / \mathrm{h})^{\prime}$ & 195.7 & 57.5 & $118-292$ \\
\hline $\begin{array}{l}\text { Graminoid production } \\
(\mathbf{k g} / \mathbf{h})^{1}\end{array}$ & 46.0 & 49.4 & $0-164$ \\
\hline
\end{tabular}
production than the single variable models.

\section{Shrub Production}

Three overstory characteristics were significant in predicting shrub production. Canopy coverage, as a single independent varia-
Table 2. Mean $(\bar{x})$, standard deviation (s) and range of the overstory and understory variables studied in the grand fir/myrtle boxwood habitat type in the Clearwater Mountains of Idaho.

'Dry weight.

ble, had the highest correlation with shrub production (Table 4, Fig. 2).

Other overstory structures significantly correlated with shrub production were sum of the tree diameters and basal area with $R^{2}$ values of 0.67 and 0.34 respectively (Table 4 ).

None of the multiple variable models accounted for significantly greater portions of variability than the single variable model.

\begin{tabular}{|c|c|c|c|c|c|c|c|}
\hline \multirow[b]{2}{*}{ Species ${ }^{1}$} & \multirow[b]{2}{*}{ Common name } & \multicolumn{2}{|c|}{$\begin{array}{l}\text { Sum of the diameters } \\
(\mathrm{m} / \mathrm{ha})\end{array}$} & \multicolumn{2}{|c|}{$\begin{array}{l}\text { Basal area } \\
\text { (m/ha) }\end{array}$} & \multicolumn{2}{|c|}{$\begin{array}{c}\text { Stand density } \\
\text { (trees/ha) }\end{array}$} \\
\hline & & $\bar{x}$ & $s$ & $\overline{\bar{x}}$ & $s$ & $\bar{x}$ & $s$ \\
\hline Abies grandis & grand fir & 112.2 & 53.7 & 24.8 & 18.6 & 849.4 & 685.6 \\
\hline Larix occidentalis & mountain larch & 3.4 & 9.1 & 1.3 & 3.5 & 12.0 & 36.2 \\
\hline Picea engelmanii & engelmann spruce & 10.0 & 23.7 & 3.2 & 8.7 & 37.8 & 76.1 \\
\hline Pinus contorta & lodgepole pine & .3 & 1.1 & .1 & .2 & 1.4 & 6.0 \\
\hline Pinus ponderosa & ponderosa pine & 3.8 & 11.4 & 2.0 & 6.3 & 9.4 & 21.7 \\
\hline Pseudotsuga menziesii & Douglas fir & 17.0 & 41.8 & 5.5 & 14.6 & 87.8 & 131.2 \\
\hline Taxis brevifolia & pacific yew & 1.0 & 4.3 & .7 & 2.9 & 8.0 & 35.8 \\
\hline
\end{tabular}

$$
\begin{gathered}
Y=-289.9+52279.0 X^{-1} \\
R^{2}=.7635
\end{gathered}
$$

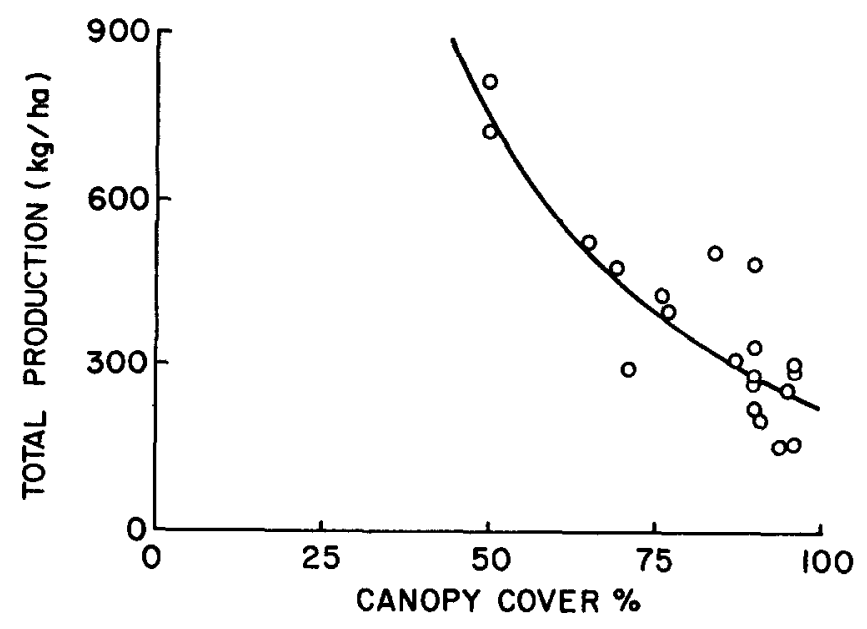

Fig. 1. The relationship between total production (dry weight) and overstory canopy coverage in the grand fir/myrtle boxwond habitat type of the Clearwater Mountains of Idaho.

Table 1. Mean $(\bar{x})$ and standard deviation $(s)$ for three overstory structural features of tree species encountered in stands of grand fir/myrtle boxwood habitat type in the Clearwater Mountains of Idaho.

'Nomenclature follows Hitchcock and Cronquist (1973). 
Table 3. Constancy, canopy coverage, and rooted frequency for selected species encountered in stands of the grand fir/myrtle boxwood habitat type in the Clearwater Mountains of Idaho.

Species ${ }^{1,2}$

Understory trees

Abies grandis

Pseudotsuga menziesii

Shrubs

Acer glabrum

Amelanchier alnifolia

Chimaphila menziesii

Chimaphila umbellata

Linnaea borealis

Lonicera ciliosa

Lonicera utahensis

Pyrola secunda

Ribes lacustre

Ribes viscosissimum

Rosa gymnocarpa

Rubus parviflorus

Symphoricarpos albus

Vaccinium membranaceum

Xerophyllum tenax

Perennial graminoids

Bromus vulgaris

Carex rossii

Festuca occidentalis

Perennial forbs

Adenocaulon bicolor

Anemone piperi

Arenaria macrophylla

Clintonia uniflora

Coptis occidentalis

Fragaria vesca

Galium triflorum

Goodyera oblongifolia

Hieracium albiflorum

Mitella stauropetala

Osmorhiza chilensis

Pedicularis racemosa

Smilacina stellata

Thalictrum occidentalis

Tiarella trifoliata

Trillium ovatum

Viola orbiculata

Common name

grand fir

Douglas fir

rocky mountain maple

western serviceberry

little prince's pine

prince's pine

twinflower

trumpet honeysuckle

Utah honeysuckle

sidebells pyrola

prickly current

sticky current

baldhip rose

thimbleberry

common snowberry

big huckleberry

beargrass

columbia brome

ross sedge

western fescue

trail-plant

piper's a nemone

bigleaf sandwort

beadlily

Idaho goldth read

woods strawberry

sweetscented bedstraw

western rattlesnake plantain

white-flowered hawkweed

side-flowered miterwort

mountain sweetroot

leafy lousewort

starry solomon-plume

western meadowrue

foamflower

western trillium

darkwoods violet
Canopy coverage $^{3}$ Rooted frquency ${ }^{3}$

Constancy

(\%)

$(\%)$

$(\%)$

$\bar{x} \pm s_{\bar{x}}$

'Nomenclature follows Hitchcock and Cronquist (1973).

2Only those species which have constancies of $50 \%$ or greater are shown.

'Values represent averages based only on those macroplots in which the species was found.

${ }^{4} \mathrm{~T}=$ less than $0.5 \%$ coverage.

\section{Forb Production}

Overstory ca nopy coverage was the only significant, single va riable related to forb production $\left(R^{2}=0.32\right)$ (Table 4 , Fig. 3). A multiple independent variable model combining overstory canopy coverage and sume of the tree diameters accounted for a significantly greater $(\alpha \leq 0.05)$ variation than the single variable model alone $\left(R^{2}=0.47\right)($ Table 4$)$.

\section{Graminoid Production}

The graminoid production was not significantly correlated with any of the measured overstory structures in both single and multiple independent variable models.

\section{Discussion}

Overstory canopy coverage, as measured with a spherical densiometer, was the best single independent variable for predicting the production of all understory vegetation classes except graminoids. Reifsnyder and Lull (1965) demonstrated a high correlation between overstory canopy coverage, as measured with a spherical densiometer, and light intensity and net radiation at the forest floor. Vezina and Pech (1964) and Reifsnyder and Lull (1965) have shown that measured light interception can be 60 to $100 \%$ in the range of canopy coverages examined in our study depending upon needle and branch density in the canopy of the stand.

The spherical densiometer integrates several structural features of the overstory into a single measurement of canopy coverage. Because of the convex curvature of the mirror, the view of the overstory canopy is like that of a wide angle lens with an infinite depth of field. At the center of the mirror, crown width is the predominant structural tree feature observed. Near the periphery of the mirror within the estimation grid, crown length, vertical bole area, and bole density become increasingly important structural features contributing to canopy coverage. The spherical densiometer accounts for a large portion of the total overstory which can inhibit light penetration to the understory, especially light penetrating the canopy from low angles.

Sum of tree diameters was found to be a good predictor of shrub 


$$
\begin{gathered}
Y=-414.9+42899.0 X^{-1} \\
R^{2}=.7999
\end{gathered}
$$

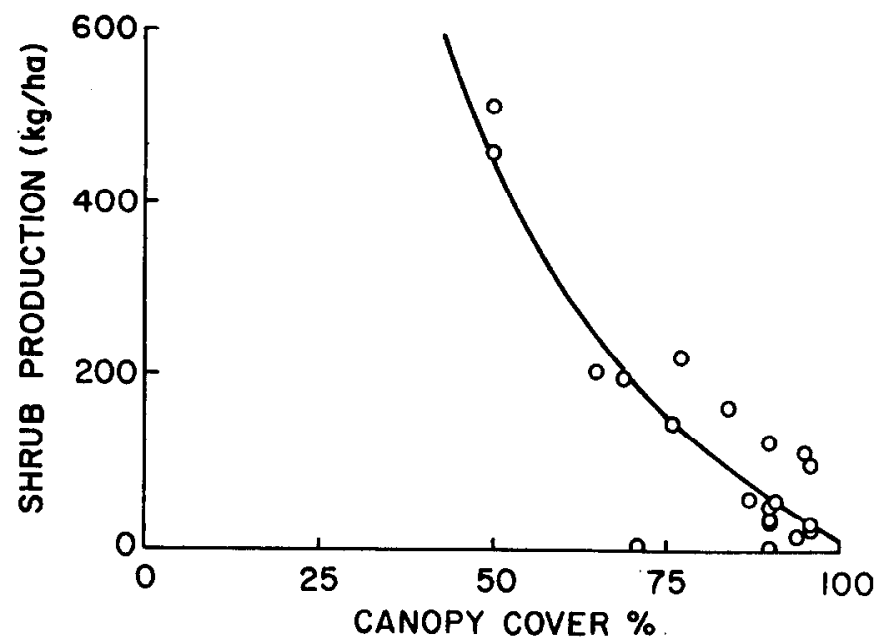

Fig. 2. The relationship between shrub production (dry weight) and overstory canopy coverage in the grand fir/myrtle boxwood habitat type of the Clearwater Mountains of Idaho.

and total understory production. This variable is easily measured and calculated and is readily available from timber survey data. This parameter has been shown to be closely related to the length and basal width of live tree crown (Arnold 1948), and also a good index of the transmission of solar radiation (Miller 1959, Reifsnyder and Lull 1965, Wellner 1948, Vezina and Pech 1964).

In contrast to sum of tree diameters, basal area was a poor predictor of all understory production classes. Basal area gives little weight to small bole diameter trees which can provide a substantial amount of light intercepting crown (Miller 1959). Basal area will generally increase with stand age and will not consistently reflect changes in the canopy due to the establishment or death of small bole diameter trees.

It is important to realize that sum of tree diameters and basal area do not completely represent the mass and distribution of the canopy that intercepts light in a forest stand. Assmann (1970) concluded that stem dia meter and area cannot be considered at all times as a close correlate to canopy structure. In a completely

$$
\begin{gathered}
Y=380.01-2.2400 X \\
R^{2}=.3216
\end{gathered}
$$

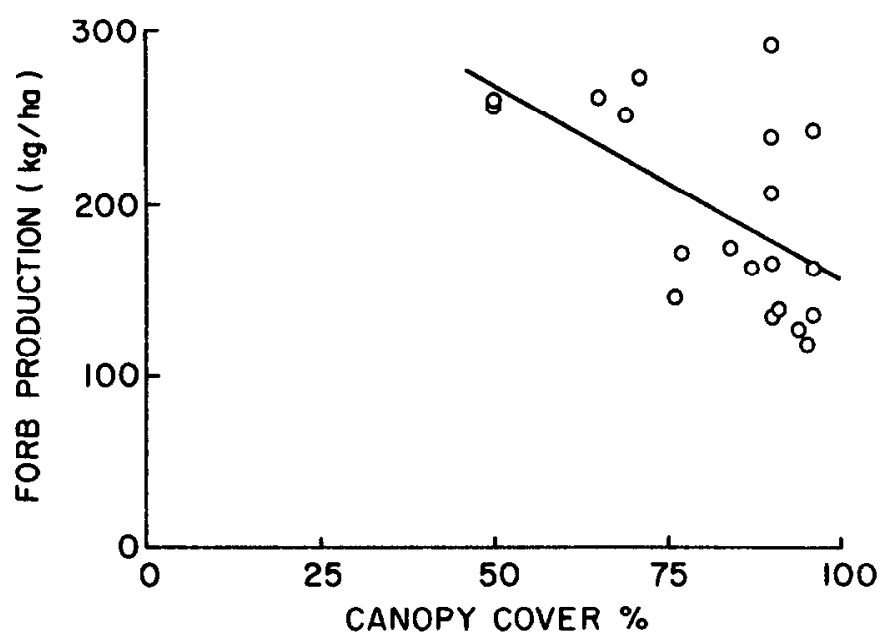

Fig. 3. The relationship between forb production (dry weight) and overstory canopy coverage in the grand fir/myrtle boxwood habitat type of the Clearwater Mountains of Idaho.
Table 4. Coefficients of determination $\left(R^{2}\right)$ and regression equations for estimating production ( $Y$ ) in $\mathbf{k g} / \mathrm{ha}$ of understory vegetation using sum of the diameters of tree (S) in $\mathrm{m} / \mathrm{ha}$, overstory tree canopy coverage (C) in $\%$ and basal area (B) in $\mathrm{m}^{2} / \mathrm{ha}$ as independent variables for the grand fir/myrtle boxwood habitat type in the Clearwater Mountains of Idaho. All models are significant at $\alpha \leq 0.01$.

\begin{tabular}{llll}
\hline $\begin{array}{l}\text { Vegetation } \\
\text { class }\end{array}$ & $\begin{array}{l}\text { Independent } \\
\text { variables }\end{array}$ & Model & $R^{2}$ \\
\hline Total Production & $\mathrm{Y}=-289.9+52279.0 \mathrm{C}^{-1}$ & .7635 \\
& $\mathrm{C}$ & $\mathrm{Y}=81.0+39048.7 \mathrm{~S}^{-1}$ & .5362 \\
& $\mathrm{~S}$ & $\mathrm{Y}=-414.9+42899.0 \mathrm{C}^{-1}$ & .7999 \\
Shrubs & & $\mathrm{Y}=-131.6=34891.4 \mathrm{~S}^{-1}$ & .6661 \\
& $\mathrm{C}$ & $\mathrm{Y}=65.3+5129.9 \mathrm{~B}^{-1}$ & .3385 \\
& $\mathrm{~S}$ & & \\
Forbs & $\mathrm{B}$ & $\mathrm{Y}=388.5-3.6 \mathrm{C}+0.7 \mathrm{~S}$ & .4738 \\
& & & .3216 \\
\hline
\end{tabular}

closed stand where latcral growth of the crown is limited, stem diameters will continue to increase. When such a stand is thinned to substantially reduce canopy coverage, crown size increases at a faster rate than the stem diameters. Bole measurements serve only as estimations of canopy structure which actually intercepts solar radiation, where spherical densiometer measurements will more accurately reveal changes in the canopy.

Stand height as a single independent variable was least correlated with production in all vegetation classes. When stand height was entered into a two variable model with canopy coverage or the inverse of canopy coverage, significantly correlated models were derived with coefficients of determination greater than models containing canopy coverage alone. Yet $F$-tests demonstrated that no significant additional variance was explained by the addition of stand height.

Stem density was not significantly correlated with any of the vegetation classes in single or multiple independent variable regression models. This could be attributed to the fact that as the canopy develops the stem density may remain constant and thus not reflect the decrease in light penetration to the understory.

Graminoid production was the only understory vegetation class not correlated with any of the measured overstory structural features. Thirteen species of graminoids were encountered among all the stands sampled; however, only 3 contributed significantly to understory production. These were, in decending order of abundance, columbia brome, ross sedge, and western fescue (Table 3 ). Graminoid production varied from $0-57 \mathrm{~kg} /$ ha under both high and low canopy coverage. Daubenmire and Daubenmire (1968) showed similar variation in graminoid abundance among climax stands of the grand fir/myrtle boxwood habitat type of northern Idaho and eastern Washington. The results of Daubenmire (1953) and Moir (1966) suggest that the soil nutrient status may be a major factor determining the growth response of graminoids under shaded conditions.

\section{Conclusions}

Our results indicate that understory production is closely correlated with overstory canopy coverage and sum of the tree diameters on undisturbed sites of the grand fir/myrtle boxwood habitat type. Since both overstory characteristics are good indices of solar radiation transmission through tree canopies to the understory, the data indicate that solar radiation is a major limiting factor of understory production in this study area. Both overstory characteristics are easily measured, and in the case of tree diameters, readily available from timber survey data. Use of such parameters would greatly facilitate estimation of understory production for range inventory purposes. Further examination of the models is needed to verify 
these relationships over the range of the grand fir/myrtle boxweed habitat type.

\section{Literature Cited}

Anderson, R.C., O.L. Loucks, and A.M. Swain. 1969. Herbaceous response to canopy cover, light intensity, and throughfall precipitation in coniferous forests. Ecology 50:255-263.

Arnold, D.L. 1948. Growing space ratio as related to form and development of western white pine. M.S. thesis (Forestry), Univ. Idaho, Moscow, $48 \mathrm{p}$.

Assmann, E. 1970. The Principles of Forest Yield Study. Pergamon Press Inc., Elmsford, New York, 506 p.

Clary, W.P., and P.F. Ffolliott. 1966. Differences in herbage-timber relationships between thinned and unthinned ponderosa pinestands. USDA FS Res. Note RM-74, 4 p.

Cooper, W.P. 1960. Production of native and introduced grasses in the ponderosa pine region of Arizona. J. Range Manage. 13:214-215.

Daubenmire, R. 1953. Nutrient content of leaf litter of trees in the northern Rocky Mountains. Ecology 34:786-793.

Daubenmire, R. 1959. A canopy-coverage method of vegetational analysis. Northw. Sci. 33:43-64.

Daubenmire, R., and J.B. Daubenmire. 1968. Forest vegetation of eastern Washington and northern Idaho. Washington, Agr. Exp. Sta. Tech. Bull. $60,104 \mathrm{p}$.

Ehrenreich, J.H., and J.S. Crosby. 1960. Herbage production is related to hardwood crown cover. J. Forestry 58:564-565.

Gaines, E.H., R.S. Campbell, and J.J. Brasington. 1954. Forage production on longeaf pine lands of southern Alabama. Ecology 35:59-62.
Halks, L.R., and J.L. Shuster. 1965. Tree-herbage relations in pinehardwood forests of Texas. J. Forestry 63:282-283.

Helwig, J.T., and K.A. Council, ed. 1979. SAS User's Guide 1979 Edition. SAS Institute Inc. Raleigh, N.C., 494 p.

Hitchcock, C.L., and A. Cronquist. 1973. Flora of the Pacific Northwest. Univ. Washington Press. Seattle, Wash. 730 p.

Jameson, D.A. 1967. The relationship of tree overstory and herbaceous understory vegetation. J. Range Manage, 20:247-249.

Lemmon, P.E. 1956. A spherical densiometer for estimating forest overstory density. Forestry Sci. 3:314-320.

McConnell, B.R., and J.G. Smith. 1965. Understory response three years after thinning pine. J. Range Manage. 18:129-132.

McConnell, B.R., and J.G. Smith. 1970. Response of understory vegetation to ponderosa pine thinning in eastern Washington. J. Range Manage. 23:208-212.

Miller, D.H. 1959. Transmission of isolation through pine forest canopy as it affects the melting snow. Scheiz. Anst. f. Forstl. Versuchsw. Mitt. 35:57-79.

Moir, W.H. 1966. Influence of ponderosa pine on herbaceous vegetation. Ecology 47:1045-1048.

Mueggler, W.F.1976. Number of plots required for measuring productivity on mountain grasslands in Montana. USDA FS Res. Note INT-207,6 p.

Reifsnyder, W.E., and H.W. Lull. 1965. Radiant energy in relation to forests. USDA FS Tech. Bull. 1344, 111 p.

Vezina, P.E., and G.Y. Pech. 1964. Solar radiation beneath conifer canopies in relation to crown closure. Forestry Sci. 10:443-451.

Wellner, C.A. 1948. Light intensity related to stand density in mature stands of the western white pine type. J. Forestry 46:16-19.

Young, J.A., D.W. Hedrick, and R.K. Keniston. 1967. Forest cover and logging-herbage and browse production in the mixed coniferous forest of northeastern Oregon. J. Forestry 65:807-813.

\section{In-Place Resource Inventories
Principles and Practices \\ Proceedings of a National Workshop}

In August 1981, a state-of-the-art workshop on in-place resource inventories convened at Orono, Maine, with 441 resource professionals in attendance. Cosponsors were the Society of American Foresters, American Society of Photogrammetry, Society for Range Management, The Wildlife Society, and the Renewable Natural Resources Foundation.

The Society of American Foresters is pleased to announce publication of the workshop proceedings. Papers by 274 authors fill 1,101 pages in a paperback, 81/2-by-11-inch volume. Pertinent photographs-aerial and ground-line drawings, computer and conventional maps, charts, and graphs are used extensively for illustration and clarification. Postpaid price for the proceedings is \$30. In-Place Resource Inventories is a timely document on a subject crucial to resource management. Reserve a copy now.

Society of American Foresters
5400 Grosvenor Lane - Bethesda, Md. 20814
I wish to order $\quad$ Inventories: Principles and Practices.
Tutal \$__ames
Address
State
Alease encluse payment.

